ology, 66: 1218 (1974)

21. Odell, G. B.: Neonatal hyperbilirubinemia. pp. $44-47$ (Grune and Stratton, New York, 1980).

22. Cukier, J. L., Maglalang, A. C., and Odell, G. B.: Increased osmotic fragility of erythrocytes in chronically jaundiced rats after phototherapy. Acta Paediatr. Scand. 68: 903 (1979).

23. Malloy, H. T., Evelyn, K. A.: The determination of bilirubin with the photoelectric colorimeter. J. Biol. Chem. 119: 481 (1937).

24. Schwarz, M. P., von Bergman, K., and Paumgartner, G.: A simple method for the estimation of bile acids in serum. Clin. Chim. Acta, 50: 197 (1974).

25. Boyer, J., Baron, D. N., and Talalay, P.: Purification and properties of a $3 \alpha-$ hydroxysteroid dehydrogenase from Pseudomonas testosteroni. Biochemistry, 4: 1825 (1965)

26. Brownlee, K. A.: Industrial experimentation. 4th edition (Chemical Publishing Co., New York, 1953)

27. Dixon, W. J., Massey, F. J., Jr.: Introduction to statistical analysis. 3rd edition (McGraw-Hill Co., New York, 1969).

28. Arrowsmith, W. A., Payne, R. B., and Littlewood, J. M.: Comparison of treat- ments for congenital non-obstructive non-haemolytic hyperbilirubinemia. Arch. Dis. Child. 50: 197 (1975).

29. McDonagh, A. F., Palma, L. A., and Lightner, D. A.: Blue light and bilirubin excretion. Science, 208: 145 (1980).

30. John, E.: Complications of phototherapy in neonatal hyperbilirubinemia. Aust. Paediatr. J., 11: 53 (1975).

31. Rubaltelli, F. F., and Largajolli, G.: Effect of light exposure on gut transit time in jaundiced newborns. Acta Paediatr. Scand., 62: 146 (1973).

32. Whitington, P. F., Olsen, W. A., and Odell, G. B.: The effect of bilirubin on the function of hamster small intestine. Pediatr. Res., 15: 1009 (1981).

33. Li, B., Whitington, P. F., and Odell, G. B.: Reversal of bilirubin-induced small bowel secretion by agar. Pediatr. Res., 13: 403A (1979).

34. Requests for reprints should be addressed to: Dr. G. B. Odell, Department of Pediatrics, University of Wisconsin Clinical Science Center, 600 Highland Avenue, Madison, WI 53792 USA.

35. These studies have been supported by USPHS Grant AMDD \#21668.

36. Received for publication April 24, 1981.

37. Accepted for publication March 1, 1983

\title{
A Mechanism for Liver Cell Injury in Viral Hepatitis: Effects of Hepatitis B Virus on Neutrophil Function in Vitro and in Children with Chronic Active Hepatitis
}

\author{
ALBERTO VIERUCCI, MAURIZIO DE MARTINO, ELISA GRAZIANI, MARIA E. ROSSI, W. THOMAS \\ LONDON, AND BARUCH S. BLUMBERG ${ }^{(63)}$
}

\author{
Division of Immunology, Institute of Pediatrics, University of Florence, Florence, Italy, and Institute for Cancer
}

Research, Fox Chase Cancer Center, Philadelphia, Pennsylvania USA

\begin{abstract}
Summary
Neutrophil function was studied by nitroblue tetrazolium (NBT) reduction, superoxide anion $\left(\mathrm{O}_{2}{ }^{\bar{\sigma}}\right)$ production, chemotaxis, and bactericidal activity in 9 children with HBsAg-positive chronic active hepatitis (CAH). NBT reduction and $\mathrm{O}_{2}^{-}$production were higher in resting neutrophils from the children with $\mathrm{CAH}$ than from the controls, but the production of $\mathrm{O}_{2}{ }^{-}$was depressed after stimulation with zymosan. No defect was observed in both random and direct locomotion, whereas a significant decrease was present in bactericidal activity. To evaluate the role of virus components, purified preparations of $\mathrm{HBsAg}$ and $\mathrm{HBcAg}$ were added to neutrophils from normal children. The incubation with such products induced in vitro the same modifications that were observed in the neutrophils from children with CAH. In addition, defects in phagocytosis and killing of Candida albicans as well as in chemotaxis were demonstrated. The production of $\mathrm{O}_{2}{ }^{-}$was reduced in the neutrophils, stimulated by zymosan and previously opsonized with HBsAg-positive serum.
\end{abstract}

\section{Abbreviations}

CAH, chronic active hepatitis

HBcAg, hepatitis B core antigen

HBsAg, hepatitis B surface antigen

HBV, hepatitis B virus

KRP, Krebs Ringer Phosphate
NBT, nitroblue tetrazolium

PMA, phorbolmyristate acetate

PMNs, polymorphonuclear neutrophils

SGOT, serum aspartate aminotransferase

SGPT, serum alanine aminotransferase

The mechanism by which HBV causes liver damage is unclear (35). Because individuals with persistent HBV infection and large numbers of virus particles in their blood frequently have little or no liver damage but patients with transient infections often have low titers of circulating HBV particles and severe liver damage, most investigators have concluded that viral replication, itself, is not the cause of liver cell death. Because patients with impaired immune functions (lepromatous leprosy, end stage renal disease, leukemia, etc.) are more likely to develop persistent infections than persons without impaired immune responses, several investigators have proposed that it is the immune response to HBV that is responsible for the damage to hepatocytes $(8,40)$. Recently, Dienstag et al. (14) and Levy and Chisari (35) reviewed various hypotheses that have been proposed to explain how lymphocytes or antibodies might be involved in the liver damage of hepatitis. They concluded that there was insufficient evidence to support any particular cellular or humoral mechanism.

An alternative possibility is that phagocyte cells, i.e., PMNs and macrophages, may be involved in at least type B hepatitis. Alter- 
ations in neutrophil function have been reported both in acute $(37,50)$ and in chronic hepatitis patients, as shown by reduced phagocytic activity $(12,56)$ and depressed chemotaxis $(37)$. We previously observed that the bactericidal activity of neutrophils was reduced in children who were chronic carriers of HBsAg (57), most of whom had evidence of liver damage (13). We also demonstrated that the neutrophils of these patients had an activation of oxidative metabolism without phagocytosis, as shown by a higher proportion of stimulated PMNs in the NBT test (57). Similar observations had been reported by Hellum and Solberg (27) in patients with acute viral hepatitis (type unspecified).

Monocytes from patients with chronic hepatitis have shown high production and release of lysosomal enzymes, even without the stimulation of phagocytosis, suggesting that these cells had already been activated (20). Bradfield and Wells (10) indicated that Kupffer cells play an important role in the pathogenesis of hepatitis. Other investigators $(17,55)$ demonstrated in animal models that activation of macrophages may result in enhanced degranulation, release of lysosomal enzymes, and liver injury.

In this study we present data indicating that neutrophils (which represent a large compartment of circulating phagocytic cells) showed impaired function in children with chronic HBsAg-positive hepatitis. This alteration could be reproduced in in vivo experiments using PMNs from normal individuals exposed to purified $\mathrm{HBV}$ components, i.e., $\mathrm{HbsAg}, \mathrm{HBcAg}$, or to $\mathrm{HBsAg}$ positive serum. HBV components were able to promote a respiratory burst in resting PMNs with subsequent formation of the oxygen free radical $\mathrm{O}_{2}{ }^{\top}$. We suggest that the formation of free radicals from chronically stimulated phagocytes plays a significant role in the pathogenesis of liver damage in patients with chronic HBsAg-positive hepatitis, and that this mechanism is probably important in the pathogenesis of chronic hepatitis.

\section{MATERIALS AND METHODS}

This study included nine children, 3-14 years of age, with $\mathrm{HBs} \mathrm{Ag}$-positive CAH diagnosed by the histologic criteria of Bianchi et al. $(6,7)$. All the patients presented high levels of amino transferases (SGPT and SGOT transaminases) for more than 1 year. HBsAg and HBsAb were detected by radioimmunologic methods (AUSTRIA and AUSAB, Abbott Lab., N. Chicago, IL). Controls consisted of as many sex- and age-matched children who were not infected with $\mathrm{HBV}$. The clinical data of both groups are summarized in Table 1.

Separation of neutrophils. Venous blood was drawn into siliconized glass tubes containing $10 \mathrm{IU}$ heparin per $\mathrm{ml}$ of blood. Mononuclear cells and platelets were separated from PMNs and red cells by centrifugation of Ficol-Isopaque $\left(\Delta=1.007 \mathrm{~g} / \mathrm{cm}^{3}\right.$ at $20^{\circ} \mathrm{C}$ ). Erythrocytes were removed by sedimentation for $45 \mathrm{~min}$ at $4^{\circ} \mathrm{C}$ in $6 \%$ dextran (molecular weight 500,000 Pharmacia Fine Chemicals, Inc., Piscataway, NJ) in saline, and those which still remained were lysed with $0.2 \% \mathrm{NaCl}$. Isotonicity was restored with an equal volume of $1.6 \% \mathrm{NaCl}$. PMNs were washed and resuspended in the buffer used in the particular experiment (usually KRP). This preparation did not interfere with the oxidative metabolism and function of cells. Cell viability was determined by the exclusion of $1 \%$ trypan blue dye.

Assay of locomotion. A modification of the method of Zigmond and Hirsch (60) was used as described by Wilkinson (58), which employs cellular suspensions containing $5 \times 10^{3} \mathrm{PMNs} / \mathrm{ml}$ in Sykes-Moore chambers or lucite blind well chemotactic chambers (Nucleopore, Pleasantown, CA) with a 5- $\mu \mathrm{m}$ millipore filter (Millipore Corp., Bedford, MA) to separate the upper from the lower compartment of the chambers.

Casein was used as the chemoattractant after solubilization in Hank's balanced salt solution by gently increasing the $\mathrm{pH}$ with $\mathrm{NaOH}$ to 12 and subsequent restoration to neutrality with $1.0 \mathrm{M}$ $\mathrm{NaH}_{2} \mathrm{PO}_{4}$. A concentration of casein of $5 \mathrm{mg} / \mathrm{ml}$ was used in the attractant compartment. The chambers were incubated at $37^{\circ} \mathrm{C}$ for $45 \mathrm{~min}$ and the filters were fixed with ethanol and stained with
Table 1. Clinical, biochemical, and serologic data of nine children with chronic active hepatitis and as many controls ${ }^{1}$

\begin{tabular}{|c|c|c|c|c|c|c|}
\hline & Sex & $\begin{array}{l}\text { Age at } \\
\text { diagnosis } \\
(\mathrm{yr})\end{array}$ & HBsAg & $\begin{array}{l}\text { anti- } \\
\text { HBs }\end{array}$ & SGOT $^{2}$ & SGPT $^{3}$ \\
\hline \multicolumn{7}{|c|}{ Patients } \\
\hline 1 & $\mathrm{~F}$ & 7 & + & - & 55 & 50 \\
\hline 2 & $\mathbf{M}$ & 10 & + & - & 73 & 71 \\
\hline 3 & $\mathbf{M}$ & 3 & + & - & 64 & 53 \\
\hline 4 & $\mathbf{M}$ & 7 & + & - & 39 & 63 \\
\hline 5 & $\mathbf{M}$ & 14 & + & - & 35 & 75 \\
\hline 6 & $F$ & 9 & + & - & 54 & 80 \\
\hline 7 & $F$ & 13 & + & - & 48 & 77 \\
\hline 8 & $\mathbf{M}$ & 12 & + & - & 78 & 100 \\
\hline 9 & $\mathbf{M}$ & 12 & + & - & 268 & 191 \\
\hline \multicolumn{7}{|c|}{ Controls } \\
\hline 1 & $\mathrm{~F}$ & $71 / 2$ & - & - & 11 & 19 \\
\hline $\mathrm{p} \quad 2$ & $\mathbf{M}$ & 10 & - & + & 9 & 12 \\
\hline 3 & M & $2 \frac{1}{2}$ & - & - & 21 & 13 \\
\hline 4 & $\mathbf{M}$ & 6 & - & - & 7 & 9 \\
\hline 5 & $\mathbf{M}$ & 14 & - & - & 14 & 15 \\
\hline 6 & $\mathrm{~F}$ & 9 & - & - & 19 & 11 \\
\hline 7 & $\mathrm{~F}$ & 13 & - & + & 10 & 21 \\
\hline 8 & $\mathbf{M}$ & 12 & - & - & 18 & 12 \\
\hline 9 & $\mathbf{M}$ & 11 & - & - & 14 & 17 \\
\hline
\end{tabular}

'Abbreviations: $\mathrm{HBsAg}$, hepatitis B surface antigen; HBs, antibody against HBsAg; SGOT, serum asparatate aminotransferase; and SGPT, serum alanine aminotransferase.

${ }^{2} \mathrm{IU} /$ liter, normal range $7-40$.

${ }^{3} \mathrm{IU} /$ liter, normal range $5-25$.

hematoxylin. Triplicate chambers were run in each case, and the distance $(\mu \mathrm{m})$ travelled by the leading front was measured at $\times 400$ magnification. Five randomly chosen fields of cells were read for each filter and the results were pooled and the mean determined. Experiments performed using serum inactivated with $1 \mu \mathrm{g} / \mathrm{ml}$ of $E$. coli endotoxin produced analogous results.

In order to calculate the random migration, cells in Hank's balanced salt solution were allowed to migrate toward the medium without any chemoattractant.

In five experiments neutrophils from normal children were first incubated with $0.1 \mathrm{ml}$ of $\mathrm{HBsAg}$-positive serum or with purified HBsAg $(250 \mu \mathrm{g} / \mathrm{ml})$, or $\mathrm{HBcAg}(200 \mu \mathrm{g} / \mathrm{ml})$ at $37^{\circ} \mathrm{C}$ for $30 \mathrm{~min}$. Purified HBsAg, prepared by density gradient centrifugation (42) and a preparation of $\mathrm{HBcAg}$ from a liver of a $\mathrm{HBsAg}$-positive chronic hepatitis patient (38), were denoted by Dr. I. Millman of the Institute for Cancer Research, Philadelphia, PA.

Bactericidal and candidacidal activity of neutrophils. Bactericidal activity of PMNs was assayed by the method of Quie et al. (46). $E$. coli 0125 B were kindly supplied by the Sclavo Institute, Sienna, Italy. Bacterial cells, $2.5 \times 10^{6}$, and leukocytes, $2.5 \times 10^{6}$, were removed from patients and put in $1 \mathrm{ml}$ of KRP containing $10 \%$ normal serum. Cells were incubated at $37^{\circ} \mathrm{C}$. Samples were removed at $0,15,30$, and $60 \mathrm{~min}$. In four experiments bactericidal activity was tested in normal PMNs after 30 min' incubation with $40 \mu \mathrm{g}$ of purified HBsAg, or $100 \mu \mathrm{l}$ of HBsAg-positive serum. Controls were performed using the same neutrophils incubated with $100 \mu$ l of KRP or normal serum. After incubation cells were washed twice and bactericidal activity was assayed as reported above, also including a reading at $120 \mathrm{~min}$. The number of viable $E$. coli was determined by colony count using the pourplate technique after $24 \mathrm{~h}$ incubation at $37^{\circ} \mathrm{C}$, and was expressed as a $\%$ of the survival of the initial number of bacteria.

Candidacidal activity was evaluated by the method of Brune $e t$ al. (11) with minor modifications. Briefly, neutrophils from normal control children suspended in $100 \mu 1 \mathrm{KRP}$ were allowed to adhere to slides and were incubated at $37^{\circ} \mathrm{C}$ for $30 \mathrm{~min}$ with $100 \mu \mathrm{l}$ of $\mathrm{KRP}$ alone or containing $25 \mu \mathrm{g}$ of $\mathrm{HBsAg}$ or $10 \mu \mathrm{g}$ of $\mathrm{HBsAg}$. 
After incubation, slides were washed in KRP and exposed to 100 $\mu 1$ of $2 \times 10^{6}$ Candida albicans suspended in $25 \%$ fresh normal human serum. After $50 \mathrm{~min}$ incubation at $37^{\circ} \mathrm{C}$, methylene blue ( $2 \times 10^{-4}$ in Hank's solution) was added to stain dead phagocytized Candida albicans blue; living cells remained unstained. The following estimates were made: phagocytic index $=\%$ phagocytizing PMNs; avidity index = mean number of ingested Candida albicans/phagocytizing PMNs; candidacidal activity = \% phagocytized Candida albicans which were killed.

Oxidative metabolism. Unstimulated and stimulated neutrophils from patients and controls were assayed by both the histochemical NBT test and superoxide anion production $\left(\mathrm{O}_{2}{ }^{\top}\right)$. The histochemical NBT test was done by the method of Park et al. (45) as modified by Gifford and Malawista (21). In addition, PMNs were stained with Samson dye, fixation with methanol was avoided and slides were read immediately. The $\%$ of NBT-positive neutrophils in normal children ranged from $0-12 \%($ mean $=6.5)$. The stimulated NBT test was performed with antigen/antibody complexes from horse antiserum to human serum proteins or human serum. It showed that $89-97 \%$ of neutrophils were NBT-positive in controls. The production of superoxide anion was determined both in patients and controls by the reduction of cytochrome $c$ according to the method of Bellavite et al. (5), which assays the release of $\mathrm{O}_{2}{ }^{-}$ from leukocytes in whole blood as well as from purified preparations of PMNs. The assay mixture consisted of $1.0 \mathrm{ml}$ of $2.3 \mathrm{mM}$ cytochrome $c$ in KRP; $1 \times 10^{6}$ PMNs in $0.2 \mathrm{ml}$ of either whole blood or purified preparations. The mixture was brought to a final volume of $1.0 \mathrm{ml}$ with KRP. Paired reactions were performed employing $50 \mu \mathrm{g}$ of superoxide dismutase (Sigma Chemical Corp., St. Louis, MO). To stimulate the respiratory burst, zymosan (Sigma Ch. Corp., St. Louis, MO), phorbolmyristate-acetate (PMA) (Sigma Ch. Corp., St. Louis, MO), or purified preparations of HBsAg or HBcAg were used. Zymosan was prepared by boiling in saline for $15 \mathrm{~min}$ and then washed three times in the same medium. It was subsequently opsonized at $37^{\circ} \mathrm{C}$ for $30 \mathrm{~min}$ with $10 \%$ normal serum in KRP, and then washed and adjusted to a concentration of $10 \mathrm{mg} / \mathrm{ml}$ in KRP; $0.1-\mathrm{ml}$ amounts were used in the test. In five experiments zymosan was opsonized with normal or HBsAg-positive serum to stimulate normal PMNs. PMA $(0.2$ $\mathrm{mg} / \mathrm{ml}$ in dimethylsulfoxide) was used in the amount of $0.1 \mu \mathrm{g}$ in the test. Purified preparations of $\mathrm{HBsAg}$ and $\mathrm{HBcAg}$ were used at a concentration of 250 and $100 \mu \mathrm{g} / \mathrm{ml}$ respectively; $10^{6}$ normal neutrophils were preincubated with $0.1 \mathrm{ml}$ of these preparations and washed twice in KRP before testing.

The viability of PMNs was evaluated after incubation in all the experiments, which included preincubation of these cells with purified HBsAg, $\mathrm{HbcAg}$ or $\mathrm{HBsAg}$-positive serum.

\section{RESULTS}

Locomotion. Random migration did not show significant differences between children with HBsAg-positive $\mathrm{CAH}$ and the HBsAg-negative controls. There were also no statistically significant differences between children with $\mathrm{CAH}$ and the controls in the test for chemotaxis (Fig. 1). The effect of HBsAg-positive serum and of purified HBsAg and HBcAg on the chemotaxis of PMNs from normal children is shown in Figure 2. These cells presented a reduction of chemotaxis higher than $40 \%$ with respect to values obtained after incubation with normal serum; no differences were observed between the inhibition obtained with $\mathrm{HBs} \mathrm{Ag}$, $\mathrm{HBcAg}$ or HBsAg-positive serum.

Bactericidal and Candidacidal activity. Killing of $E$. coli by neutrophils from children with $\mathrm{CAH}$ and from normal children was similar after 15 and $30 \mathrm{~min}$ incubation. Survival of $E$. coli was significantly greater after $60 \mathrm{~min}$ incubation with neutrophils from children with $\mathrm{CAH}$ than with cells from the controls $(P<$ 0.01) (Fig. 3). As shown in Table 2, incubation with either purified HBsAg or HBsAg-positive serum resulted in a significant decrease in the bactericidal activity of normal neutrophils. Inhibition of this function was significantly greater with purified HBsAg than with $\mathrm{HBsAg}$-positive serum and was more positive after $120 \mathrm{~min}$ incubation.

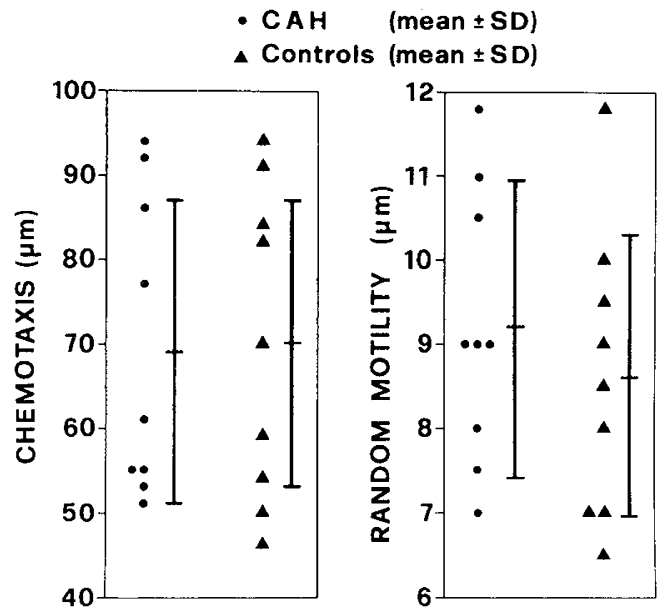

Fig. 1. Chemotaxis and random motility of neutrophils from children with chronic active hepatitis $(\mathrm{CAH})$ and controls. The vertical bars represent \pm 1 S.D.

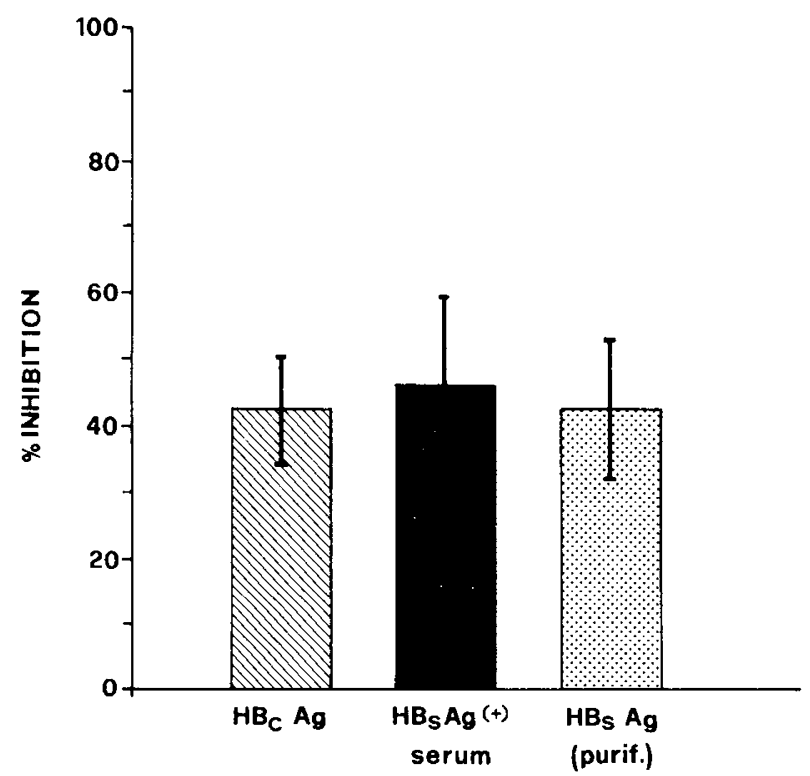

Fig. 2. \% inhibition of chemotaxis in neutrophils from normal children preincubated with $\mathrm{HBcAg}$, $\mathrm{HBsAg}$-positive serum or $\mathrm{HBsAg}$ (purified preparation).

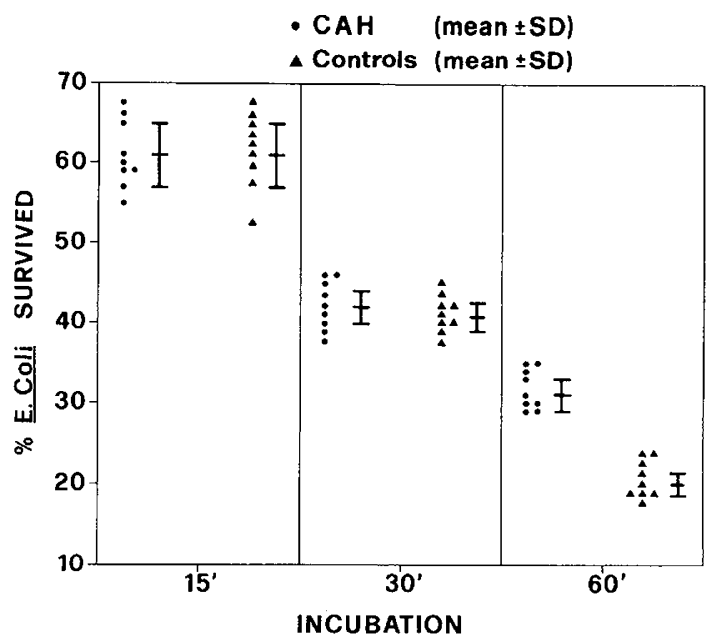

Fig. 3. Bactericidal activity of neutrophils from children with chronic active hepatitis $(\mathrm{CAH})$ and controls. Data are expressed as \% bacteria survived after 15,30 , and $60 \mathrm{~min}$ incubation. 
Phagocytic index, avidity index, and candidacidal activity of normal PMNs incubated with HBsAg, HBcAg, and KRP are shown in Figure 4. HBcAg appeared to significantly $(P<0.01)$ inhibit the phagocytic index (Fig. 4, column $a$ ), the avidity index (Fig. 4, column b), as well as the candidacidal activity (Fig. 4, column $c$ ). HBsAg affected the avidity index (Fig. 4, column $b$ ) $(P<0.01)$ and the candidacidal activity (Fig. 4, column $c)(P<$ 0.01 ), but not the phagocytic index.

Oxidative metabolism. NBT reduction was increased in all nine children with $\mathrm{HBsAg}$-positive $\mathrm{CAH}$ when unstimulated PMNs were tested compared with normal children $(P<0.01)$ (Fig. 5 , column $a$ ). Values in the stimulated NBT test obtained by using antigen/antibody complexes were similar in patients and controls (Fig. 5, column $b$ ).

The production of $\mathrm{O}_{2}{ }^{-}$showed significant differences between resting PMNs from children with $\mathrm{CAH}$ and from normal children $(P<0.01)$ (Fig. 6, column a). After stimulation with zymosan, PMNs from children with CAH showed reduced capacity to produce $\mathrm{O}_{2}{ }^{-}$compared with cells from normal children $(P<0.01)$ (Fig. 6, column $b$ ). On the contrary, stimulation with PMA did not reveal a significant difference between the two groups of children (Fig. 6, column $c$ ). In the experiments done with PMNs from normal children stimulated with zymosan opsonized with normal serum or with HBsAg-positive serum, the production of

Table 2. Bactericidal activity of normal neutrophils incubated with normal or hepatitis B surface antigen (HBsAg)-positive sera or with HBsAg (mean \pm S.D. of quadruplicate experiments)

\begin{tabular}{cccc}
\hline & \multicolumn{2}{c}{$\%$ Bacteria survived } & \\
\cline { 2 - 3 } & $\begin{array}{c}\text { Incubation } \\
=60 \mathrm{~min}\end{array}$ & $\begin{array}{c}\text { Incubation } \\
=120 \mathrm{~min}\end{array}$ & $P^{1}$ \\
\hline System & $22.25 \pm 2.21$ & $7.84 \pm 1.12$ & \\
$\begin{array}{l}\text { (a) Normal neutrophils } \\
+ \text { normal serum }\end{array}$ & $49.0 \pm 1.82$ & $16.63 \pm 4.69$ & $<0.01$ \\
$\begin{array}{l}\text { (b) Normal neutrophils } \\
+ \text { HBsAg(+) serum }\end{array}$ & $64.75 \pm 2.98$ & $22.65 \pm 4.95$ & $<0.01$ \\
$\begin{array}{l}\text { (c) } \begin{array}{l}\text { Normal neutrophils } \\
+ \text { HBsAg }\end{array} \\
\text { HBAs }\end{array}$ & & &
\end{tabular}

${ }^{1} a$ vs $b$ and $c$ after 60 and $120 \mathrm{~min}$ incubation.
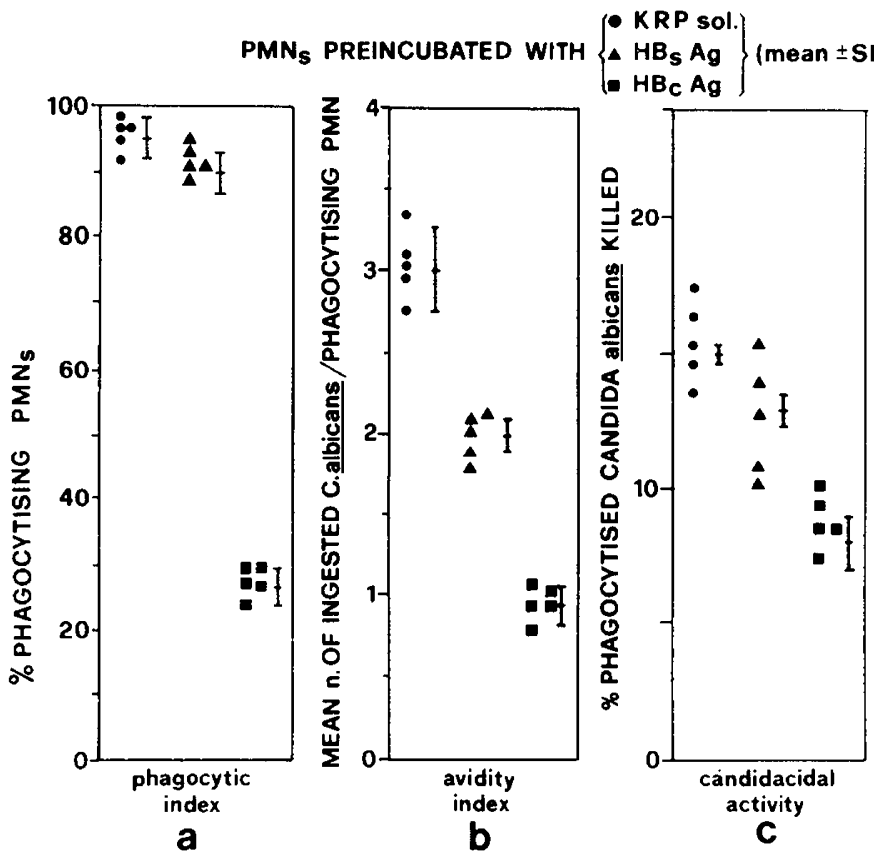

Fig. 4. Phagocytic index (a), avidity index (b), and candidacidal activity (c) of normal neutrophils after incubation with either purified HBsAg or $\mathrm{HBcAg}$.

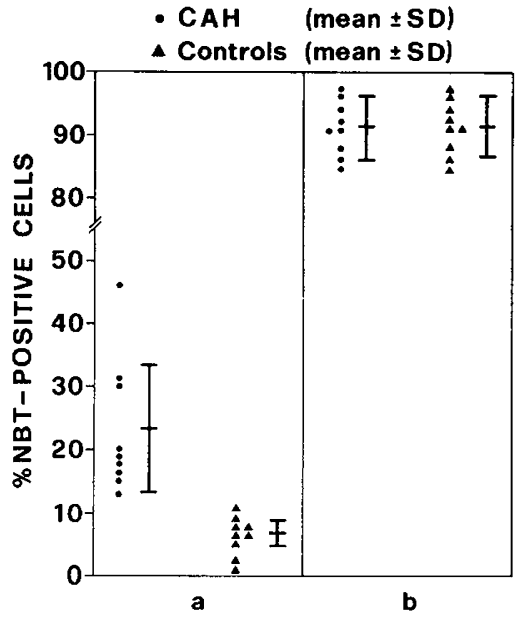

Fig. 5. Unstimulated (a) and stimulated (b) NBT test in neutrophils from children with chronic active hepatitis $(\mathrm{CAH})$ and controls.

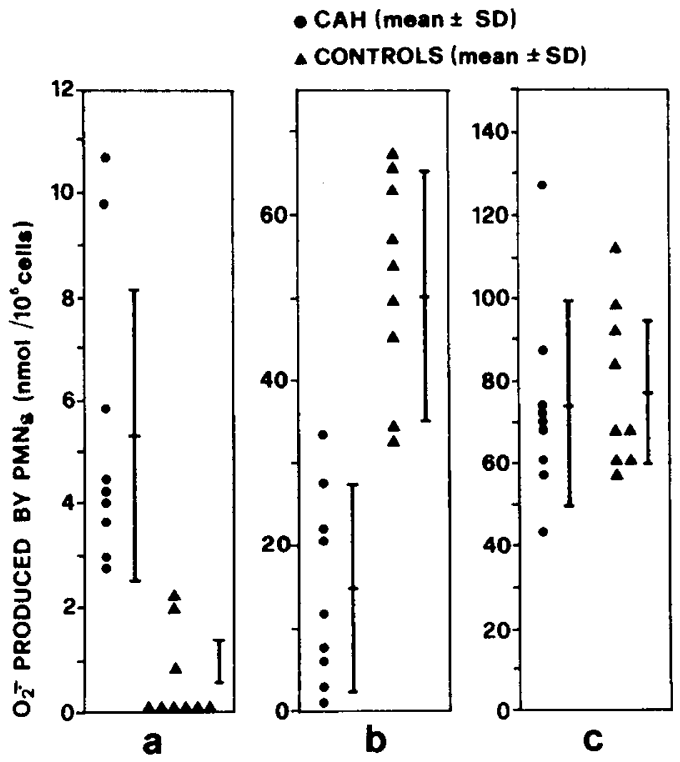

Fig. 6. Production of $\mathrm{O}_{2}{ }^{-}$by neutrophils from children with chronic active hepatitis $(\mathrm{CAH})$ and controls, in resting state $(a)$ and after stimulation with zymosan $(b)$ and phorbolmyristate acetate (PMA) $(c)$.

$\mathrm{O}_{2}{ }^{-}$was significantly different $(51.1 \pm 1.68$ nmole versus $37.72 \pm$ 2.73 nmole, $P<0.01$ ). The effect of zymosan and PMA on the production of $\mathrm{O}_{2}{ }^{-}$by PMNs preincubated with normal serum or HBsAg-positive serum is shown in Table 3, whereas the effect of preincubation of neutrophils from normal children with purified preprations of $\mathrm{HBsAg}$ and $\mathrm{HBcAg}$ is illustrated in Table 4. As shown in these tables, preincubation of neutrophils with HBsAgpositive serum or with purified preparations of $\mathrm{HBsAg}$ and $\mathrm{HBcAg}$ resulted in a significant increase in $\mathrm{O}_{2}{ }^{-}$production when unstimulated cells were tested. This is in agreement with the observation that unstimulated neutrophils from children with HBsAg-positive CAH had a higher production of $\mathrm{O}_{2}{ }^{-}$and a higher $\%$ of NBT reducing cells, compared with neutrophils from normal children. On the other hand, phagocytosis of zymosan particles opsonized with either HBsAg-positive serum or normal serum in neutrophils preincubated with $\mathrm{HBsAg}$ or $\mathrm{HBcAg}$ induced a lower $\mathrm{O}_{2}{ }^{-}$production and decreased bactericidal activity. A normal production of $\mathrm{O}_{2}{ }^{-}$was obtained from neutrophils exposed to $\mathrm{HBsAg}$ and stimulated with PMA, under the same conditions as with zymosan. A significant decrease, however, was observed when neutrophils were preincubated with $\mathrm{HBcAg}$. 


\section{DISCUSSION}

In this study we observed that children with HBsAg-positive CAH have alterations of neutrophil function consisting of: (1) increase in oxidative metabolism of resting cells as demonstrated by the increase of $\mathrm{O}_{2}{ }^{*}$ generating activity and the increase in NBT reduction in unstimulated cells; (2) reduced $\mathrm{O}_{2}{ }^{-}$formation after stimulation of phagocytosis with activated zymosan; and (3) reduced capacity to kill ingested bacteria after $60 \mathrm{~min}$ incubation.

We tested the hypothesis that these functional modifications were related to the presence of HBV components. This was done by incubating normal neutrophils with purified HBsAg and HBcAg preparations before carrying out the functional assays. Alterations in function similar to those observed in neutrophils from HBsAg-positive children were induced in vitro. These included reduced phagocytosis and the killing of Candida albicans and of $E$. coli, an increase of oxidative metabolism in unstimulated neutrophils, and a decrease in $\mathrm{O}_{2}{ }^{-}$production after zymosan stimulation. One effect observed in vitro but not in neutrophils from children with CAH was a reduction of chemotaxis. This is similar to what has been observed with Herpes simplex by Kleinerman et al. (33), with measles by Anderson et al. (2), and with influenza virus by Ruutu et al. (48). Because no defect in chemotaxis was demonstrated in neutrophils from the affected children, some compensatory mechanism(s) may be operating in vivo.

The most interesting finding in this study was that HBsAgpositive sera, as well as HBV components, were able to induce a respiratory burst in neutrophils, as demonstrated by release of $\mathrm{O}_{2}{ }^{\circ}$. Conversely, the same neutrophils showed a marked reduction in $\mathrm{O}_{2}{ }^{-}$production when stimulated with opsonized zymosan; however, stimulation of neutrophil respiratory burst obtained with PMA after preincubation with $\mathrm{HBsAg}$, under analogous experimental conditions, yielded an efficient response. PMA is able to induce functional modifications similar to those observed during phagocytosis (47) and may activate an oxidative mechanism different from the one activated by opsonized zymosan (39). A similar observation was reported by Winston et al. (59) in neutrophils exposed to cytomegalovirus. Initiation of the respiratory

Table 3. Release $e^{1}$ of $\mathrm{O}_{2}{ }^{-}$by normal neutrophils preincubated with either normal serum or hepatitis $B$ surface antigen (HBsAg)positive serum (mean $\pm S . D$. of quintuplicate experiments)

\begin{tabular}{lccc}
\hline & \multicolumn{2}{c}{ Neutrophils preincubated with } & \\
\cline { 2 - 3 } \multicolumn{1}{c}{ Stimulus } & Normal serum & HBsAg(+) serum & $P$ \\
\hline None & $1.96 \pm 0.92$ & $10.32 \pm 1.51$ & $<0.01$ \\
Zymosan & $61.20 \pm 4.54$ & $14.54 \pm 1.42$ & $<0.01$ \\
$\begin{array}{l}\text { Phorbolmyristate } \\
\text { acetate }\end{array}$ & $115.24 \pm 14.88$ & $101.50 \pm 4.15$ & NS \\
\hline
\end{tabular}

${ }^{1}$ Expressed as nmole/ $10^{6}$ PMNs. burst in neutrophils, similar to that induced by $\mathrm{HBV}$, has recently been demonstrated for virus-antibody complexes of influenza virus (43) and syncytial virus (31). The production of toxic oxygen radicals might provide a defense mechanism against some viruses in the absence of specific antibodies. This could have harmful effects by impairing subsequent phagocytic function $(34,36)$. We do not know whether the increased level of superoxide stimulated by viruses reflects increased production or decreased detoxification by enzymes such as superoxide dismutase or catalase which are present in hepatocytes.

The activation of the respiratory burst in neutrophils is primarily related to antimicrobial defense (4), but it is also possible that oxygen radicals may be involved in mechanisms of inflammation and tissue damage (19). Oxygen radicals have been reported to induce peroxidation in lysosomal membranes (18), depolymerize hyaluronate (9), influence the growth and differentiation of myoblasts (41), activate platelet function (25) and cause endothelial (49) and lung damage $(29,53)$. Neutrophils stimulated by Con A produce free radicals that are cytotoxic to chicken erythrocytes (24), whereas stimulation by PMA induces formation of oxygen species within rat renal glomeruli, which may result in glomerular injury (52). Recently, it has been reported that the formation of oxygen free radicals interferes with lymphocyte function, leading to cell membrane damage (44). Further, it has been suggested that in rheumatoid arthritis, iron stored within synovial membranes catalyzes the production of hydroxylic radicals and subsequent lipidic peroxidation (9). High iron levels have also been found in HBsAg-positive patients (15), in $\beta$-thalassemia and in chronic active hepatitis (16). Iron might be responsible for the formation of radicals toxic for hepatocytes (23). The hypothesis can be advanced that macrophages activated through various stimuli may produce oxygen radicals that subsequently cause cellular damage. This mechanism may operate in liver tissue in the presence of iron overload or HBV or immune complexes. In acute and chronic hepatitis, immunoglobulins and immune complexes have been detected on the surface of hepatocytes $(1,3)$ where receptors for $\mathrm{Fc}$ and $\mathrm{C}_{3}$ are present (28). As observed by Johnston and Lehmeyer (30), production of $\mathrm{O}_{2}{ }^{-}$occurs after neutrophil stimulation with immune complexes. Similar observations were reported by Goldstein et al. (22) in a system in which neutrophils had been stimulated with aggregated gammaglobulins and $\mathrm{C}_{5 \mathrm{a}}$. Finally, immune complexes can alter phagocytic function (54).

From observations in the present study, we can speculate that the production of $\mathrm{O}_{2}{ }^{*}$ and other products of activated oxygen by PMNs and probably by other phagocytic cells in the presence of HBV components may contribute to the liver injury in chronic hepatitis. Such damage might be mediated by monocytes, which are similar to neutrophils with regard to the production of $\mathrm{O}_{2}{ }^{-}$ (32), and by Kupffer cells. Recently, it has been reported that cytochrome $b-245$, a major component of the oxidative system, is present in neutrophils, monocytes and macrophages (51). The above mentioned mechanisms differ from that proposed by Fer-

Table 4. Release ${ }^{1}$ of $\mathrm{O}_{2}{ }^{-}$by neutrophils from normal children preincubated with either hepatitis $B$ surface antigen (HBsAg) or hepatitis $B$ core antigen ( $\mathrm{HBCAg}$ ) purified preparations (mean $\pm S . D$. of quadruplicate experiments)

\begin{tabular}{|c|c|c|c|c|}
\hline \multirow[b]{2}{*}{ Stimulus } & \multicolumn{3}{|c|}{ Neutrophils preincubated with } & \multirow[b]{2}{*}{$P$} \\
\hline & KRP solution & HBsAg & $\mathrm{HBcAg}$ & \\
\hline \multirow[t]{3}{*}{ None } & $1.81^{\mathrm{a}} \pm 0.47$ & $8.53^{b} \pm 6.54$ & $12.52^{\mathrm{c}} \pm 4.56$ & a $v s \mathrm{c}<0.01$ \\
\hline & & & & a $v s$ b NS \\
\hline & & & & b vs c \\
\hline \multirow[t]{3}{*}{ Zymosan } & $58.93^{a} \pm 5.89$ & $19.97^{b} \pm 6.41$ & $17.02^{c} \pm 9.16$ & a $v s$ b $<0.01$ \\
\hline & & & & a $v s \mathrm{c}<0.01$ \\
\hline & & & & b $v s \mathrm{c} \quad \mathrm{NS}$ \\
\hline \multirow{3}{*}{$\begin{array}{l}\text { Phorbolmyristate } \\
\text { acetate }\end{array}$} & $77.30^{a} \pm 5.42$ & $68.95^{b} \pm 5.79$ & $63.73^{c} \pm 2.05$ & a $v s \mathrm{c}<0.01$ \\
\hline & & & & $\mathrm{a} v s \mathrm{~b} \quad \mathrm{NS}$ \\
\hline & & & & $\mathrm{b} v s \mathrm{c}$ \\
\hline
\end{tabular}

\footnotetext{
${ }^{1}$ Expressed as nmole $/ 10^{6}$ PMNs.
} 
luga and Allison (17) and by Tanner et al. (55) in which the proteolytic enzymes released by activation of macrophages may promote hepatic injury. Although both mechanisms usually operate simultaneously, in viral hepatitis the formation of toxic oxygen radicals may have an earlier and more general effect because phagocytosis and degranulation are not required. Direct stimulation of the cell membrane of neutrophils or macrophages may be sufficient. The possibility remains that cells other than phagocytes may destroy hepatocytes through a mechanism analogous to the one we have suggested. In fact, it has recently been reported that human natural killer cells may induce cytolysis of specific target cells through the production of toxic free radicals (26).

\section{REFERENCES AND NOTES}

1. Alberti, A., Realdi, G., Tremolada, F., and Spina, G. R.: Liver cells surface localization of hepatitis $B$ antigen and of immunoglobulins in acute and chronic hepatitis and cirrhosis. Clin. Exp. Immunol., 25: 369 (1976).

2. Anderson, R., Rabson, A. R., Sher, R., and Koornhof, H. J.: Defective neutrophil motility in children with measles. J. Pediatr., 8: 27 (1976).

3. Arnold, W. and Meyer Zum Buschenfelde, K. H.: Immune complex of HBcAg/ anti-HBc in nuclei of HBsAg-positive chronic liver disease. N. Engl. J. Med., 259: 818 (1977).

4. Babior, B. M.: Oxygen-dependent microbial killing by phagocytes. Part I. N Engl. J. Med., 298: 659 (1978).

5. Bellavite, P., Dri, P., Berton, G., and Zabucchi, G.: Un nuovo test di funzionalita' fagocitaria basato sulla misura della produzione di anione superossido $\left(\mathrm{O}_{2}{ }^{{ }}\right)$. I. Principi generali ed esecuzione. LAB, J. Res. Lab. Med., 8: 67 (1980).

6. Bianchi, L., DeGroote, J., Desmet, V. J., Gedigk, P., Korb, G., Popper, G., Poolsen, H., Schever, P. J., Schmid, M., Thaler, H., and Wepler, W.: Morphological criteria in viral hepatitis. Lancet, I: 333 (1971).

7. Bianchi, L., DeGroote, J., Desmet, V. J., Gedigk, P., Korb, G., Popper, G., Poolsen, H., Schever, P. J., Schmid, M., Thaler, H., and Wepler, W.: Acute and chronic hepatitis revisited. Lancet II: 914 (1977).

8. Bianchi, L. and Gudat, F.: Immunopathology of hepatitis B. In: H. Popper and F. Schaffner, (Eds.): Progress in Liver Disease. Vol. VI. pp. 371-392 (Grune \& Stratton, New York, 1979).

9. Blake, D. R., Hall, N. D., Bacon, P. A., Dieppe, P. A., Halliwell, B., and Gutteridge, J. M. C.: The importance of iron in rheumatoid disease. Lancet, II: $1142(1981)$

10. Bradfield, J. W. B. and Wells, M.: Liver disease caused by lysosomal enzymes released from Kupffer cells. Lancet, $I I: 836$, (1978).

11. Brune, K., Schmidt, L., Glatt, M., and Minder, B.: Correlation between antimicrobial activity and peroxidase content of leukocytes. Nature, 245: 209 (1973)

12. Campbell, A. C., Dronfield, M. W., Toghill, P. J., and Reeves, W. G.: Neutrophil function in chronic liver disease. Clin. Exp. Immunol., 45: 81 (1981).

13. DeMartino, M., Redi Orienti, M., Calabri, G., Novembre, E., Pisanu, C., and Vierucci, A.: La funzionalita' dei granulociti neutrofili in bambini con epatite persistente. Riv. It. Pediatr., 5: 815 (1979).

14. Dienstag, J. L., Bhan, A. K., Klingenstein, R. J., and Savarese, A. M.: Immunopathogenesis of liver disease associated with hepatitis B. In: W. Szmuness, H. J. Alter, and J. E. Maynard, (Eds.): Viral Hepatitis, 1981 International Symposium. pp. 221-237 (The Franklin Institute Press, Philadelphia, PA, 1981)

15. Felton, C., Lustbader, E. D., Merten, C., and Blumberg, B. S.: Serum iron levels and response to hepatitis B virus. Proc. Natl. Acad. Sci., 76: 2438 (1979).

16. Fargion, S., Cappellini, D. M., Sampietro, M., and Fiorelli, G.: Non specific iron in patients with beta-thalassemia trait and chronic active hepatitis. Scand. $J$. Haematol., 26: 161 (1981).

17. Ferluga, J. and Allison, A. C.: Role of mononuclear infiltrating cells in pathogenesis of hepatitis. Lancet, II: 610 (1978)

18. Fong, K. L., McCay, P. B., Peyer, J. L., Leele, B. B., and Misra, H.: Evidence that peroxidation of lysosomal membrane is initiated by free radicals produced during flavin enzyme activity. J. Biol. Chem., 249: 7792 (1973).

19. Fridovich, I.: The biology of oxygen radicals. Science, 201: 875 (1978).

20. Ganguly, N. K., Kingham, J. G. C., Lloyd, B., Lloyd, R. S., Price, C. P., Triger, P. R., and Wright, R.: Acid hydrolases in monocytes from patients with inflammatory bowel disease, chronic liver disease and rheumatoid arthritis. Lancet, $I: 1073$ (1978).

21. Gifford, R. H. and Malawista, S. E.: A simple and rapid micromethod for detecting chronic granulomatous disease of childhood. J. Lab. Clin. Med., 75: 511 (1970).

22. Goldstein, I. M., Roos, D., Kaplan, H. B., and Weissman, G.: Complement and immunoglobulin stimulate superoxide production by human leukocytes independently of phagocytosis. J. Clin. Invest., 56: 1155 (1975).

23. Grace, N. D.: Evidence for hepatic toxicity of iron. In: L. W. Powell, (Ed.): Metals and the Liver. pp. 131-142 (Marcel Dekker Inc., New York and Basel, 1978).

24. Greene, W. H., Colclough, L., Anton, A., and Root, R. K.: Lectin-dependent neutrophil-mediated cytotoxicity against chicken erythrocytes: a model of nonmyeloperoxidase-mediated oxygen-dependent killing by human neutrophils. $\mathrm{J}$. Immunol., 125: 2727 (1980).

25. Handin, R. I., Karabin, R., and Boxer, G. L.: Enhancement of platelet function by superoxide anion. J. Clin. Invest., 59: 959 (1977).

26. Helfand, S. L., Wermeister, J., and Roder, J. C.: Chemiluminescence response of human natural killer cells. I. The relationship between target cell binding, chemiluminescence, and cytolysis. J. Expl. Med., 156: 492 (1982)

27. Hellum, K. B. and Solberg, C. O.: Positive NBT test in acute and viral hepatitis. Lancet, II: 1181 (1973).

28. Hopf, U., Meyer Zum Buschenfelde, K. H., and Dierich, M. P.: Demonstration of binding sites for $\mathrm{IgG}$ and third complement component $\left(\mathrm{C}_{3}\right)$ on isolated hepatocytes. J. Immunol., 117: 639 (1976).

29. Johnson, K. J., Fantone, J. C., Kaplan, J., and Ward, P. A.: In vivo damage of rat lungs by oxygen metabolites. J. Clin. Invest., 67: 983 (1981).

30. Johnston, R. B. and Lehmeyer, Y. E.: Elaboration of toxic oxygen byproducts by neutrophils in a model of immune complex disease. J. Clin. Invest. 57: 836 (1976)

31. Kaul, T. N., Faden, H., and Ogra, P. L.: Effect of respiratory syncytial virus and virus-antibody complexes on the oxidative metabolism of human neutrophils. Infect. Immun. 125: 649 (1981).

32. Kitagawa, S., Takaku, F., and Sakamoto, S.: A comparison of the superoxidereleasing response in human polymorphonuclear leukocytes and monocytes. $\mathbf{J}$. Immunol., 125: 359 (1980).

33. Kleinerman, E. S., Snyderman, R., and Daniels, C. A.: Depression of human monocytes chemotaxis by herpes simplex and influenza viruses. J. Immunol., 113: 1562 (1974)

34. Larson, H. E., Parry, R. P., Gilchrist, C., Luquetti, A., and Tyrrell, D. A. J.: Influenza viruses and staphylococci in vitro: some interactions with polymorphononuclear leukocytes and epithelial cells. Br. J. Exp. Path., 58: 281 (1977)

35. Levy, G. A. and Chisari, F. V.: The immunopathogenesis of chronic HBV induced liver disease. Springer Semin. Immunopath., 3: 439 (1981).

36. Loosli, C. L.: Influenza and the interaction of viruses and bacteria in respiratory infection. Medicine (Baltimore), 52: 360 (1973).

37. Magliulo, E. and Benzi-Cipelli, R.: Impaired leukotaxis in viral hepatitis B. N. Engl. J. Med., 293: 303 (1975).

38. Maupas, P., Larouze, B., London, W. T., Werner, B., Millman, I., O'Connell, A., Blumberg, B. S., Saimot, G., and Payet, M.: Antibody to hepatitis-B core antigen in patients with primary hepatic carcinoma. Lancet, $I I: 9$ (1975).

39. McPhail, L. C., Henson, P. M., and Johnston, R. B.: Respiratory burst enzyme in human neutrophils. Evidence for multiple mechanisms of activation. J. Clin. Invest., 67: 710 (1981)

40. Meyer Zum Buschenfelde, K. H., Hutteroth, T. H., Arnold, W., and Hopf, U.: Immunologic liver injury: the role of hepatitis B viral antigens and liver membrane antigens as targets. In: H. Popper and F. Schaffner, (Eds.): Progress in Liver Disease. Vol. VI. pp. 407-424 (Grune \& Stratton, New York, NY, 1979).

41. Michelson, A. M. and Buckingham, M. E.: Effects of superoxide radicals on myoblast growth and differentiation. Biochem. Biophys. Res. Commun., 58: 1079 (1974).

42. Millman, I., Loeb, L. A., Bayer, M. E., and Blumberg, B. S.: Australia antigen (a hepatitis-associated antigen). Purification and physical properties. J. Expl. Med., 131: 1190 (1970)

43. Mills, E. L., Debets-Ossenkopp, Y., Verbrugh, H. A., and Verhoef, J.: Initiation of the respiratory burst of human neutrophils by influenza virus. Immunolgy, 32: 1200 (1981).

44. Nishida, Y., Tanimoto, K., and Akaoka, I.: Effect of free radicals on lymphocyte response to mitogens and rosette formation. Clin. Immunol. Immunopath., 19: 319 (1981).

45. Park, B. H., Fikrig, S. M., and Smithwich, E. M.: Infection and nitroblue tetrazolium reduction by neutrophils. Lancet, $I I: 532$ (1968).

46. Quie, P. G., White, J. G., Holmes, B., and Good, R. A.: In vitro bactericidal capacity of human polymorphonuclear leukocytes: diminished activity in chronic granulomatous disease in childhood. J. Clin. Invest., 46: 668 (1976).

47. Repine, J. E., White, J. G., Clawson, C. C., and Holmes, B. M.: The influence of phorbol-myristate-acetate on oxygen consumption by polymorphonuclear leukocytes. J. Lab. Clin. Med., 83: 911 (1974).

48. Ruutu, P., Vaheri, A., and Kosunen, T. U.: Depression of human neutrophil motility by influenza virus in vitro. Scand. J. Immunol., 6: 896 (1977).

49. Sacks, T., Moldow, C. F., Craddock, P. R., Bowers, T. K., and Jacob, S. H.: Oxygen radicals mediate endothelial cell damage by complement-stimulated granulocytes. J. Clin. Invest., 61: 1161 (1978).

50. Saunders, S. J., Dowdle, E. B., Fiskerstrand, C., Bassendine, M., and Walls, R Serum factors affecting neutrophil function during acute viral hepatitis. Gut, 19: 930 (1978).

51. Segal, A. W., Garcia, R., Goldstein, A. H., Gross, A. R., and Jones, O. T. G Cytochrome $b 245$ of neutrophils is also present in human monocytes, macrophages and eosinophils. Biochem. J., 196: 363 (1981).

52. Shah, Sudhir, V.: Light emission by isolated rat glomeruli in response to phorbolmyristate-acetate. J. Lab. Clin. Med., 98: 46 (1981).

53. Shasby, D. M., Vanbenthuysen, K. M., Tate, R. M., Shasby, S. S., McMurtry, I., and Repine, J. E.: Granulocytes mediate acute edematous lung injury in rabbits and in isolated rabbit lungs perfused with phorbol-myristate acetate: role of oxygen radicals. Am. Rev. Respir. Dis., 125: 443 (1982).

54. Starkebaum, G., Jimenez, R. A. H., and Arend, W. P.: Effect of immune complexes on human neutrophil phagocytic function. J. Immunol., 128: 141 (1982).

55. Tanner, A., Keyhani, A., Reiner, R., Holdstock, G., and Wright, R.: Proteolytic enzymes released by liver macrophages may promote hepatic injury in a rat model of hepatic damage. Gastroenterology, 80: 647 (1981).

56. Triger, D. R., Kingham, J. G. C., Lloyd, R. S., and Wright, R.: Peripheral macrophage function in patients with chronic liver disease. Gut, 18: 979 (1977). 
57. Vierucci, A., DeMartino, M., London, W. T., and Blumberg, B. S.: Neutrophil function in children who are chronic carriers of hepatitis B surface antigen. Lancet, I: 157 (1977)

58. Wilkinson, P. C.: Chemotaxis and Inflammation. p. 168 (Churchill-Livingstone, Edinburgh and London, 1974).

59. Winston, D. J., Stevens, P., Lin, C. H., and Gale, R. P.: Cytomegalovirus inhibits luminol-dependent chemiluminescence of phagocytising polymorphonuclear granulocytes. Clin. Res., 29: 392A (1981).

60. Zigmond, S. H. and Hirsch, J. G.: Effects of cytochalasin B on polymorphonuclear leukocyte locomotion, phagocytosis and glycolisis. Exp. Cell Res., 73: 383 (1972).
61. All blood sample were obtained after previous informed parental consent.

62. The authors thank Mr. Sergio Nanni and Mr. Paolo Parigi for skillful technical assistance.

63. Requests for reprints should be addressed to: Baruch S. Blumberg, M.D., Institute for Cancer Research, 7701 Burholme Avenue, Philadelphia, PA, 19111 (USA)

64. This study was in part supported by grant number 80.00605 .04 from the Italian Consiglio Nazionale delle Ricerche and by USPHS grants CA-06551, RR05539 and CA-06927 from the National Institutes of Health and by an appropriation from the Commonwealth of Pennsylvania.

65. Received for publication March 4, 1982.

66. Accepted for publication March 10, 1983.

\title{
Neutrophil and T Lymphocyte Characteristics of Two Patients with Hyper-IgE Syndrome
}

\author{
MARGARET SODERBERG-WARNER, CAROL A. RICE-MENDOZA, GUILLERMO R. MENDOZA, ${ }^{(58)}$ \\ AND E. RICHARD STIEHM \\ Division of Immunology/Allergy, Department of Pediatrics and the Center for Interdisciplinary Research in \\ Immunologic Disease, UCLA Medical Center, Los Angeles, California, USA
}

\section{Summary}

Immunologic parameters including quantitative and qualitative immunoglobulin studies, various $T$ cell functions and neutrophil chemotaxis were evaluated in two patients with the Hyper-IgE syndrome. Both exhibited pruritic dermatitis in locations atypical for atopic dermatitis, marked elevations in serum IgE levels (to $40,000 \mathrm{IU} / \mathrm{ml}$ ), recurrent staphylococcal abscesses, coarse facial features and variable chemotactic defects characteristic of this syndrome. Both patients responded favorably to courses of trimethoprim-sulfamethoxazole, particularly in helping control the cutaneous infections. We believe that this is a useful therapeutic alternative to anti-staphylococcal antibiotics and prophylactic treatment has permitted therapeutic response.

Serum IgG, IgG subclasses, IgM, and IgA were normal for age. Serum IgD was markedly deficient in one patient. Functional IgM was normal with positive isohemagglutinin titers. IgG poliovirus titers were present in both patients; however, tetanus titers were not detectable in either patient, despite repeated immunizations.

Despite normal $\mathbf{E}$ rosette numbers, subtle $\mathbf{T}$ cell abnormalities were noted with variable responses to both in vivo SK-SD, candida, and mumps skin tests and in vitro PHA-, Con A-tetanus-induced lymphocyte proliferation. Lymphocyte production of macrophage inhibitory factor and interferon and responsiveness in a mixed lymphocyte culture were normal in both patients. Considerable Con-A-induced suppressor cell activity was present in one patient, but diminished in the other.

In vivo chemotaxis determined by a Rebuck skin window, revealed a markedly delayed PMN migration in both patients during a time when both patients were clinically free of furunculosis or dermatitis. In vitro neutrophil chemotaxis was variable: maximally impaired in one patient during severe pneumonia and normalizing with clinical resolution; the low chemotactic activity of the second patient did not consistently correspond to the clinical state.

Both patients demonstrated high serum histamine levels of 75 $100 \mathrm{ng} / \mathrm{ml}$ (normal $<1 \mathrm{ng} / \mathrm{ml}$ ). The neutrophils of 8 of 11 normal adults showed significantly enhanced chemotaxis (26-52\%) in the presence of $10^{7}$ to $10^{4} \mathrm{M}$ histamine, and comparable enhancement with the same concentrations of the $\mathrm{H}_{2}$ antagonist, cimetidine (1738\%). Both histamine and cimetidine consistently depressed chemotaxis in one patient. The other patient had enhanced chemotaxis in the presence of histamine and an inconsistent response to cimetidine. Histamine and cimetidine may affect neutrophils directly via $\mathrm{H}_{2}$ receptors, indirectly via $\mathrm{H}_{2}$ feedback inhibition of basophil histamine release or by non- $\mathrm{H}_{2}$ mechanisms.

\section{Abbreviations}

CBC, complete blood count

CGD, chronic granulomatous disease

MIF, migration inhibition factor

MLC, mixed leukocyte culture

PHA, phytohemagglutin

PMN, polymorphonuclear leukocytes

Immunologic function, including quantitative and qualitative immunoglobulin studies, various $T$ cell functions and neutrophil chemotaxis was evaluated in two patients with the Hyper-IgE syndrome $(6,9,16)$. Both exhibited pruritic dermatitis, marked elevations in serum IgE levels (to $40,000 \mathrm{IU} / \mathrm{ml}$ ), recurrent staphylococcal abscesses, coarse facial features, variable chemotactic defects and $T$ cell defects characteristic of this syndrome $(6,9,11$, $12,14,16,18,23,24,27,28,53,55)$. Additionally we report a favorable therapeutic response to trimethoprim-sulfamethoxazole, similar to that reported in CGD (33).

\section{PATIENTS}

Case 1. BB is a 20-year-old white female with a history of recurrent staphylococcal skin abscesses beginning in the first 2 weeks of life. As an infant she developed recurrent sinusitis and 